\title{
Trackway of a disabled seabird
}

\author{
Andreas Wetzel \\ Geologisch-Paläontologisches Institut, Universität Basel, \\ Bernoullistrasse 32, CH-4056 Basel, Switzerland; \\ Email: andreas.wetzel@unibas.ch
}

Published online: 3 April 2018

Printed 2019 in ICHNOS, 26: 80-84

doi: $10.1080 / 10420940.2018 .1445627$

\begin{abstract}
An uncommon trackway of a seabird consisting of impressions of the right foot accompanied at the left side at the supposed position of the foot only by holes was produced by a gull having two legs, but only one foot. Foot size and stride are typical of an adult herring gull. The stride is unequal between right-left and left-right impression by $\sim 15 \%$ as the digitigrade producer experienced re-distribution of load due to the missing foot. Tracks of disabled seabirds are underrepresented in reports of both modern settings as well as the fossil record when compared with modern observations. In present time, about $2 \%$ of the seabirds have injured feet or legs. Today, however, injuries of seabirds might have increased due to human fishery activities. Actual observations show that fossilisation of such trackways is favoured by microbes preferentially growing in the impressions that are moist for a prolonged period of time.
\end{abstract}

KEYWORDS: Ichnopathology, Trackway, Preservation potential, Microbial mat 


\section{Introduction}

In his seminal paper on the ethological categories of trace fossils, Seilacher (1953) emphasised that trace fossils mainly reflect the behaviour of organisms, while the anatomy of the tracemakers is of subordinate importance, except for arthropods and vertebrates. In fact, traces and tracks produced by the latter organisms can document anatomical details; for example, the skin pattern of a foot (e.g., Díaz-Martinéz and Pérez, 2012) or the length of digits may be useful as taxonomical criterion (e.g., Sacchi et al., 2014).

Trace fossils also may record anatomical anomalies of the tracemaker ("ichnopathology", e.g., McCrea et al., 2015). Previously, Hitchcock (1858, p. 116) described a track of a dinosaur missing a digit impression as new species Antipus bifidus. Later, it was classified as "extremely doubtful species" by Lull (1904, p. 536) because he had some doubts that this trackway was produced by a dinosaur having only two toes. Then, Abel (1935) interpreted this track as documenting an injury of the tracemaker. The proof of an injury was easy as the other foot impression showed imprints of three toes. A first comprehensive summary of injuries, signs of predation and illness in the fossil record was provided by Moodie (1923). Since then additional papers about disabled tracemakers were published, among them there are Lockley et al. (1994), Ishigaki and Lockley (2010) and McCrea et al. (2015).

Trace fossils are ideal for documenting injuries of feet, especially if a part of a foot or leg is missing. In fact, it is easier to detect such injuries and pathologic symptoms from trace fossils than from a body fossil, as it is often not clear if the missing body part was lost after death, while scavengers fed on the carcass or already during life. In the latter case, excellent preservation is required to recognise the presence of cicatricial tissue. In addition, an animal produces a large number of tracks, but only one body fossil. The purpose of the present study is to illustrate trackways of disabled seabirds, to evaluate the preservation potential and to outline the implications for the fossil record of disabled organisms.

\section{Observations and interpretation}

An uncommon trackway of a seabird was found consisting of the impressions of the right foot, accompanied at the left side at the supposed position of the foot only by holes that appeared as being produced by a stick (Fig. 1). The trackway was observed on a sandy tidal flat in a shallow supratidal setting about $0.5 \mathrm{~m}$ above spring-tide level at the German North Sea a few kilometres south-southwest (SSW) of the village St. Peter-Ording (GPS coordinates $54.295376^{\circ} \mathrm{N} /$ $\left.8.609140^{\circ} \mathrm{W}\right)$. This area of the North Sea coast is located within a mesotidal regime exposed to a tidal range of about $3 \mathrm{~m}$ during neap tide and about $3.4 \mathrm{~m}$ during spring tide (BSH, 2016). The trackway was found in an area that has become planate during a heavy storm tide a day before the observations were made. 


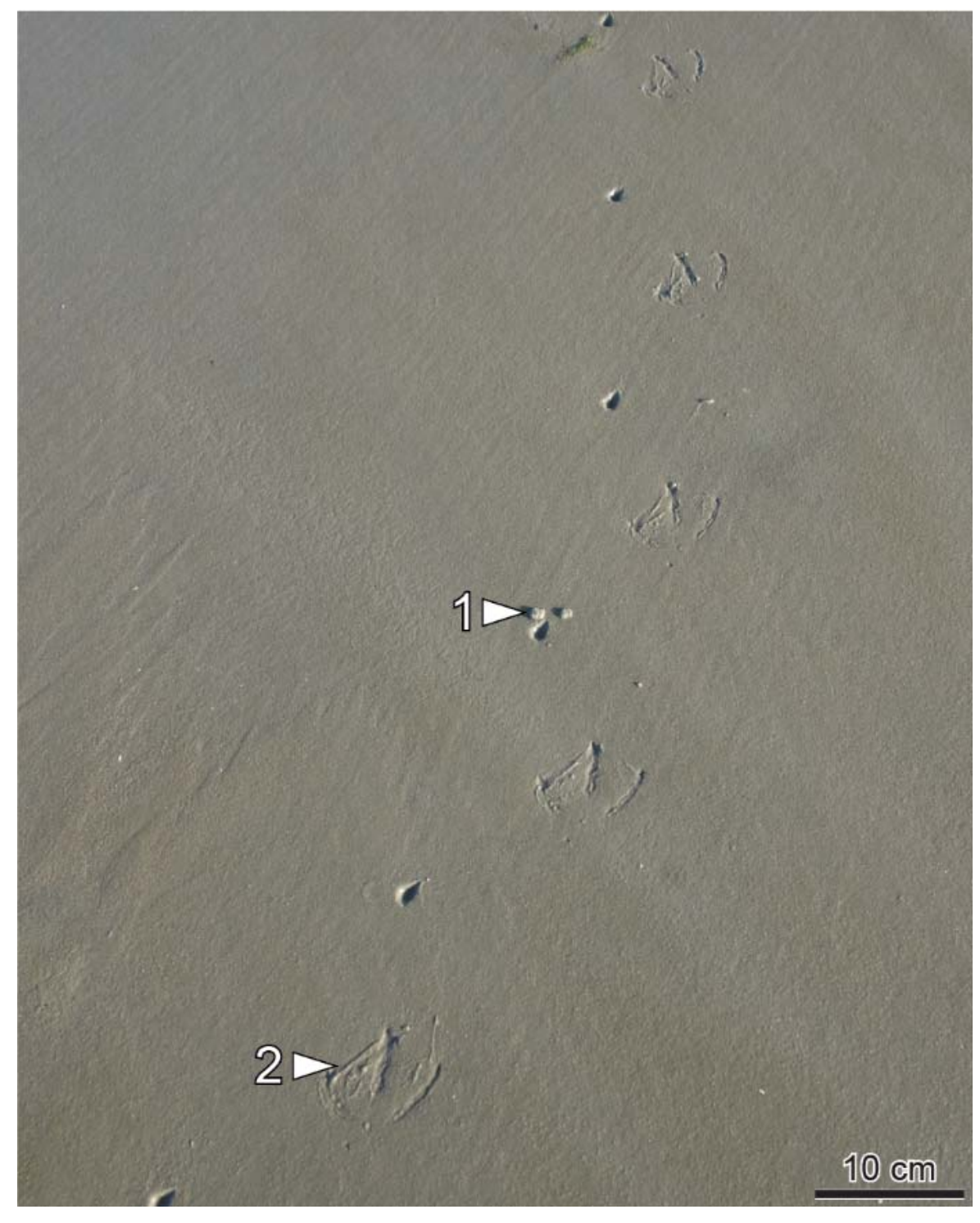

Figure 1. Trackway of a disabled gull, having two legs, but only one foot. Size of foot and stride implies that the trackway was produced by an adult herring gull (Larus argentatus). Note small sand cones adjacent to holes produced by left leg (1) and asymmetric impression of webbing of the right foot (2).

The impressions of the toes of the right foot are about 1-2 mm deep. Between the toes the margins of a palmate webbing are faintly seen (Fig. 1). The impressions of the right foot are typically of a digitigrade seabird. At the left side instead of foot impressions, holes are present as deep as 7$9 \mathrm{~mm}$. The measured depth represents a minimum value, because it is not clear if some material from the wall collapsed into the hole and accumulated on the bottom. At the anterior side next to a hole, a small sand cone may occur (Fig. 1). This pattern convincingly suggests that the left foot of the seabird was missing, but the left leg was still present, and producing the hole in the sand. When the left leg was set on the sand, it penetrated into the substrate. When the leg stump was lifted, some sand was pulled out of the hole and fell down. The interpretation of this trackway of being produced by a disabled seabird with two legs, but only one foot, is supported by the fact that 
parallel to the studied trackway another seabird trackway is present that exhibits similar size and morphology of feet, but shows impressions of two feet (Fig. 2).

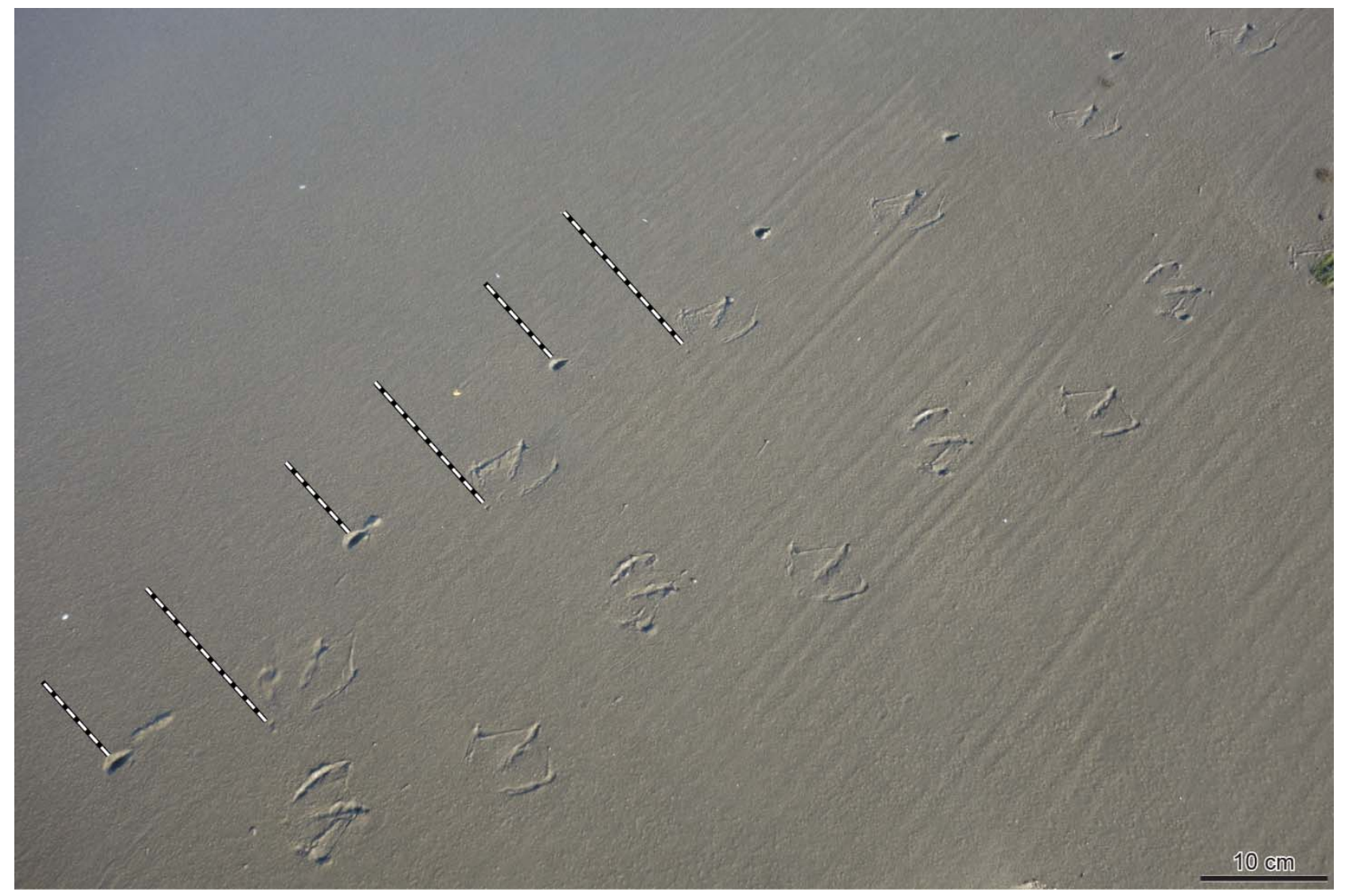

Figure 2. Trackway of a disabled and a healthy gull. The trackway of the disabled gull exhibits an unequal stride (distance left-right impression is shorter than right-left) and asymmetric loading of the right foot as the inner side sunk deeper into the sand than the outer evidenced by the impression of the margin of the webbing.

When walking, the disabled seabird did unequal steps. The distance between the centre of the right foot (approximated by the lower tip of the tarsometatarsus, i.e., the junction of toes) to the impression of the left leg stump is on average $1 / 6(=2.8 \mathrm{~cm}$ for $17 \mathrm{~cm}$ stride $)$ longer when the left stump leg is moved forward. It is, however, shorter for the same distance when the right foot is moved forward (Fig. 2). The reason for unequal steps is easy to explain: The clear impression of the toes of the right foot shows that the weight was distributed among the anterior part of the foot, which is typical of digitigrade animals, while on the left the weight of the animal was carried at a relatively posterior position by the leg stump (tarsometatarsus or tibiotarsus). The stump leg can be retrieved more easily if the complete leg is closer. Furthermore, the right foot was asymmetrically loaded. The inner part of the foot penetrated deeper into the sand than the outer part as indicated by the impression of the webbing (Fig. 1). 


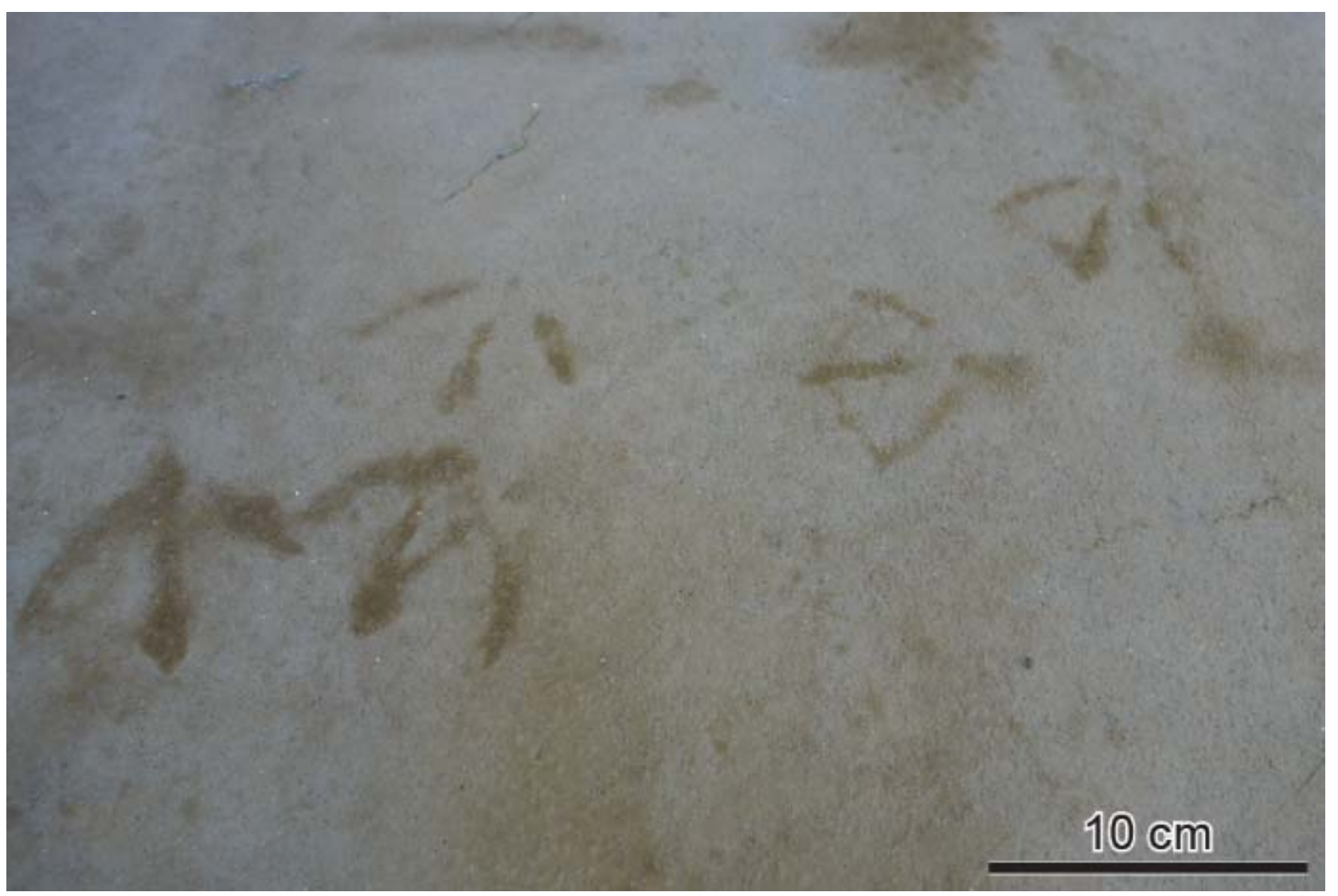

Figure 3. Preferential growths of microbes within footprints.

The impression of the right foot of the gull is rather sharp and, hence, documents its original size. Eight foot impressions were measured, and they have a nearly identical size of $7 \mathrm{~cm}$ length, $7 \mathrm{~cm}$ width and $26 \mathrm{~cm}^{2}$ area. The stride is in average $17 \mathrm{~cm}$ (modal value), while varying between 14 and $18 \mathrm{~cm}$. Stride and foot size is typical of an adult herring gull Larus argentatus (Limo) that commonly occurs in northern Europe (Elbroch and Marks, 2001; Hüppop and Hüppop, 2009). Furthermore, the trackway demonstrates that disabled gulls can survive for some time.

The weight of an adult herring gull is between 1 and $1.2 \mathrm{~kg}$ (Goethe, 1956). When walking, the foot carries in average about $40-50 \mathrm{~g} / \mathrm{cm}^{2}$. The area of the toes, however, producing the impresssion in the wet sand comprises about $1 / 4$ of the foot, meaning that the load was $\sim 160 \mathrm{~g} / \mathrm{cm}^{2}$.

Because there is only a subtle impression of the webbing, it very likely had a little influence on load distribution on wet sand. The area of the leg stump is about $1 / 2 \mathrm{~cm}^{2}$, and hence it is loaded by $2-2.4 \mathrm{~kg} / \mathrm{cm}^{2}$. The sand, therefore, was stable, while the water in partially saturated pore space caused capillary cohesion (e.g., Marston et al., 2012). As no fluidisation processes related to track production could be observed, dilation effects did not occur, and hence the sand was not water saturated (e.g., Knipe, 1989). Even during high tide the water table would be $0.2-0.5 \mathrm{~m}$ below the trackway-bearing surface and, hence, was sufficiently far below surface to facilitate capillary cohesion. 
On the short term, preservation potential of such tracks may be high, because a short while after track production microbes start to grow preferably within tracks and they flourish there during the day (Fig. 3). The impressions are moist for a prolonged time because the sand underneath is compressed and the pores are somewhat smaller facilitating capillary rise of water (e.g., Fredlund et al., 2002). Therefore, the water supply for the microbes in the footprints is more concentrated than in the uncompressed sand adjacent to them. Consequently, microbial films are formed preferentially in tracks and, hence, enhance the fossilisation potential as already stated by, for instance, Seilacher (2008), Marty et al. (2009), or Carmona et al. (2012). Another way of preservation is related to coastal winds that blow sand out of the tidal flat and deposit on the wet surface, or it may form adhesion ripples where some wetness occurs on the surface (Fig. 4). On the long term, the preservation potential is that of supratidal flats; they are located above base level and are prone to be reworked by storms. However, in case of seaward migrating coastlines in a subsiding regime receiving high amounts of sediment, they may reach the rock record.

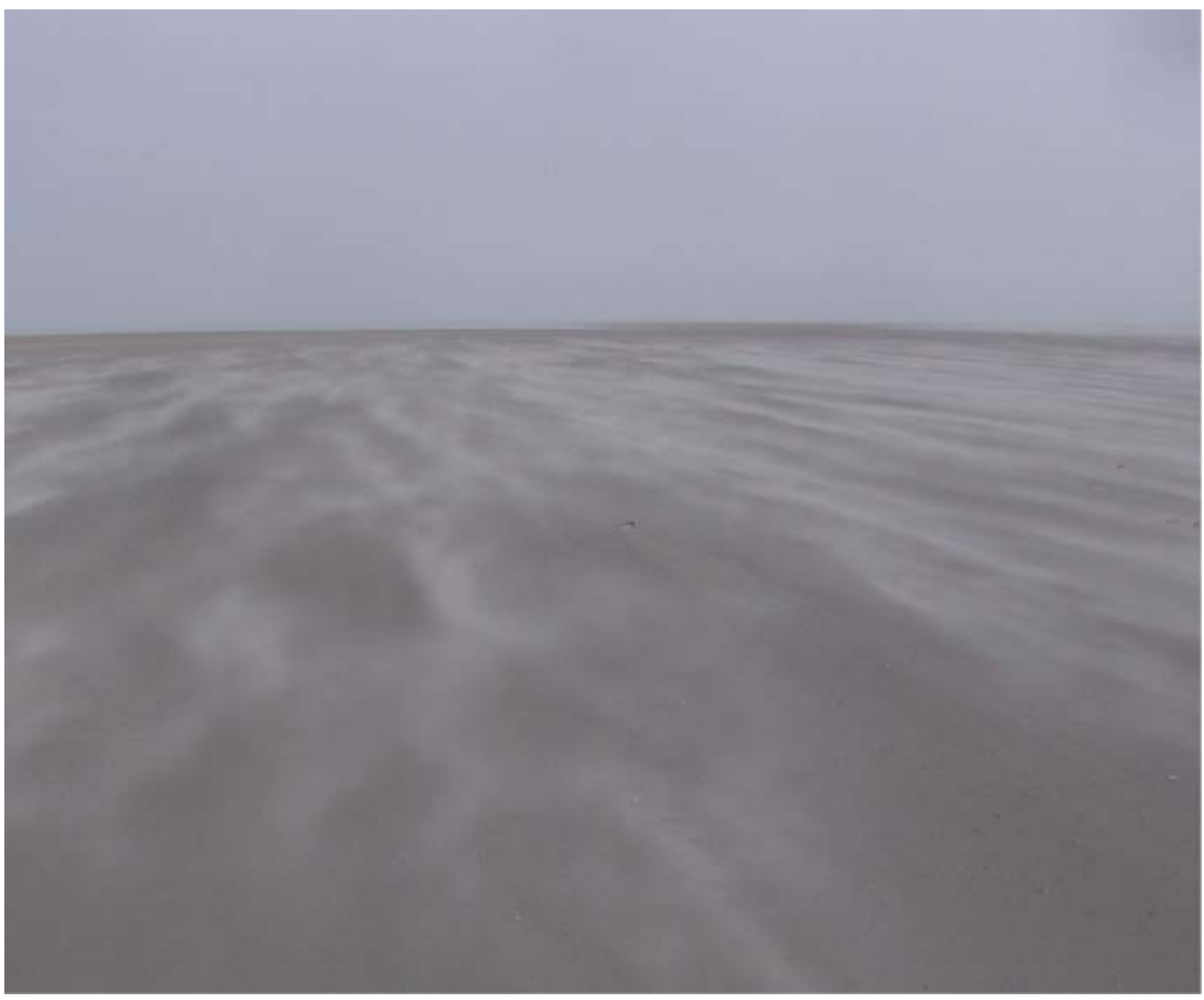

Figure 4. Coastal winds blowing out dried sand from tidal flat. 


\section{Discussion}

Wet sand has high yield strength due to capillary cohesion within a wide range of water saturation, showing maximum strength at water saturation of 50-75 weight-\% (Marston et al., 2012). Such experimental results are supported by observation. On the beach where the seabird tracks occur, cars can drive on the wet sand between water line and the dune belt. The tires produce impressions only a few millimetres deep (Fig. 5). The area of the tire touching the ground is $\sim 300 \mathrm{~cm}^{2}$, and the car weight $2.4 \mathrm{t}$. The sand is loaded by the car tire with about $2 \mathrm{~kg} / \mathrm{cm}^{2}$, which is in the range of the load carried by the leg stump of a gull.

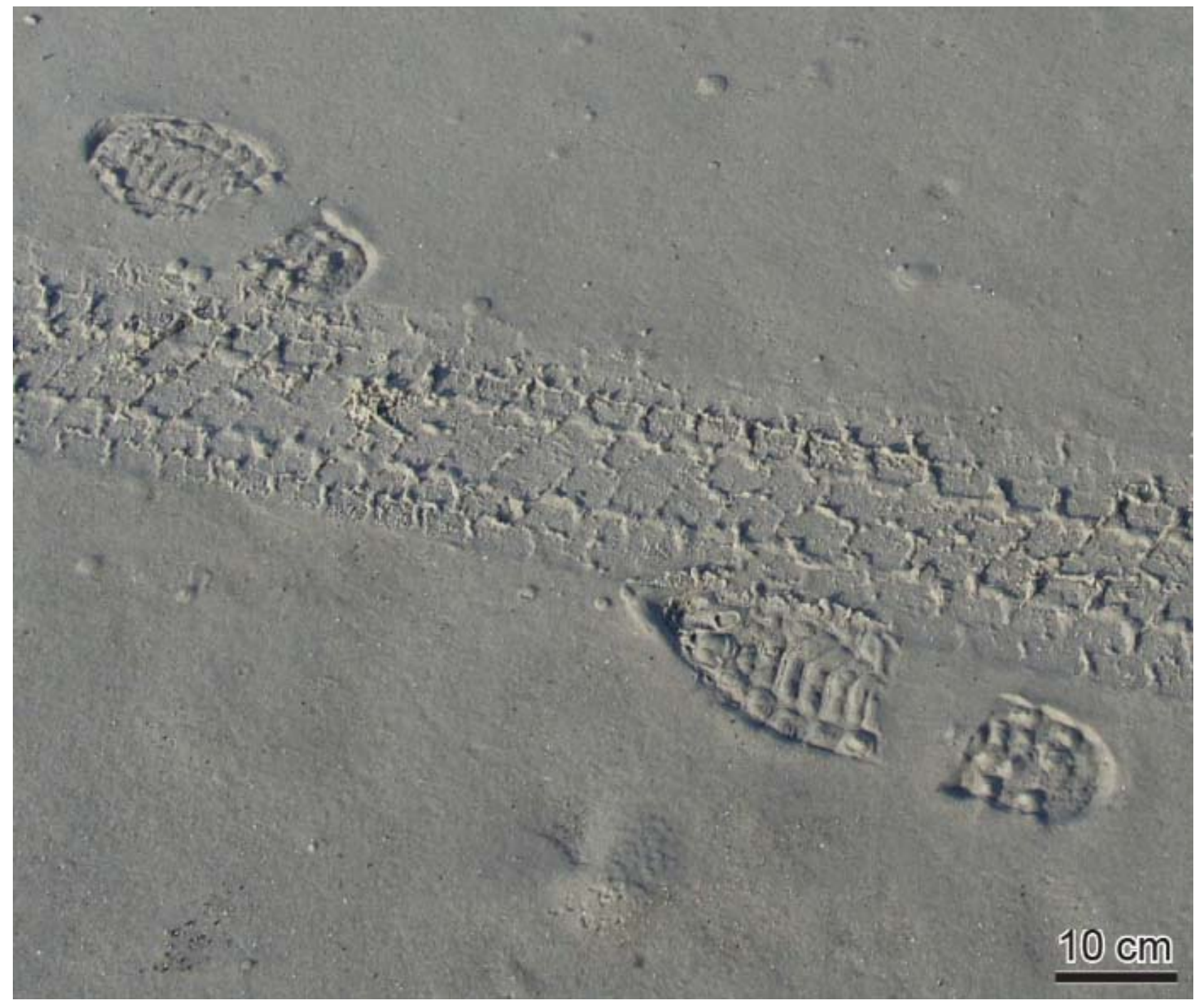

Figure 5. Shoe and tire impression on wet sand demonstrating high-bearing capacity of partially saturated sand affected by capillary cohesion.

Because of the weight carried by the left leg stump, the gull may prefer to walk on wet sand that is strengthened by capillary effects. Walking on loose or soft substrate is likely inconvenient because the leg without the foot would sink deep, maybe completely into the sediment. For retrieval, the other foot needs to be placed close to the leg with the missing foot and striding would be restricted 
to short steps. However, jumping on one leg would be an alternative form of locomotion. Therefore, as long as sand is wet, it is a suitable walking habitat for disabled seabirds as documented by the studied track. In loose sand, the preservation potential of the stump-leg impression is very low because the hole will collapse immediately after retrieval of the leg.

The loss or injury of a foot or leg is not uncommon among shore- and sea-birds. Such damage can be caused by molluscs and fishes (e.g., Barlow, 1978; Kirkham et al., 1987) and in modern times by fishery. The proportion of injured adult individuals may reach 5\% within large colonies (Morse and Buchheister, 1977). With respect to gulls, a comprehensive study based on 600 specimens of L. argentatus shot on the island of Helgoland located in the German North Sea showed that about $20 \%$ of the gulls can suffer from injuries; about $2 \%(=10 \%$ of the injuries) comprise damaged feet, disabled or missing legs. All of the disabled seabirds were able to survive; the proportion of injuries is higher in older age groups (Vauk-Hentzelt, 1982).

Gulls having lost one foot or one leg may survive for several years (Vauk-Hentzelt, 1982.). They stand on one foot as not-injured individuals often do. When walking, they can keep balance by moving their wings to unload the intact foot (Goethe, 1956). Similarly, other birds having injured legs do compensation movements using their wings or body when 'jumping' on one leg (Nothdurft, 2012).

In the recent, injuries due to fishery activities may have increased the number of disabled seabirds; however, findings of trackways of disabled seabirds are underrepresented in the rock record compared to the proportions of injuries among modern seabirds. It is very likely that the tracks of leg-injured seabirds are not recognised as such in the rock record, although the stump leg of disabled seabirds has a higher preservation potential while penetrating deeper into the substrate than the foot. However, if only the stump impression is preserved, it will not be recognised as

such. Instead, the trace made by the leg stump can be classified as part of Skolithos or as part of a vertical degassing- or dewatering-channel. Both features are not unlikely to occur in the studied environment (Reineck and Singh, 1980; Frey et al., 2009).

\section{Conclusions}

1. Trace fossils provide a better record of disabled seabirds than the body fossils, in particular if a foot or leg is injured. Today about $2 \%$ of the seabirds show leg injuries; however, this proportion is definitely higher than in pre-industrial times because additional injuries are caused by fishery and other human activities during the last decades. Nonetheless, trackways of disabled seabirds are rarely described from modern settings as well as the rock record and, hence, appear to be underrepresented, very likely while not recognised as such.

2. Foot size and stride of a trackway point to an adult producer. Therefore, it is not unlikely that a two-legged monopodal adult gull can survive for some time, as supported by the proportion of injured individual, which increases with the age of seabirds within modern colonies.

3. A disabled two-legged, but monopodal, gull can walk on wet sand stabilised by capillary cohesion. Loose or soft substrate, however, is less convenient, while the stump leg sinks too deep into the substrate. Alternatively, the gull may jump by support of wings to keep balance. 


\section{Acknowledgments}

Achim Reisdorf (Basel) helped with literature search and with preparation of the figures. A.A. Ekdale (Salt Lake City, USA) and T.J. Martin (Atlanta, USA) provided supportive discussions. All these contributions are gratefully acknowledged.

\section{References}

Abel O. 1935. Vorzeitliche Lebensspuren, 644. Jena: Fischer.

Barlow M. 1978. Deformed feet of spur-winged Plovers and Piet Stilt in southland sheep country. Notornis 25: 150.

Bundesamt für Seeschifffahrt und Hydrographie (BSH). 2016. Gezeitenvorausberechnung für St. Peter-Ording, Bad. Accessed February 26, 2016.

Carmona NB, Ponce JJ, Wetzel A, Bournod CN, Cuadrado DG. 2012. Microbially induced sedimentary structures in Neogene tidal flats from Argentina: Paleoenvironmental, stratigraphic and taphonomic implications. Palaeogeography, Palaeoclimatology, Palaeoecology 353-355: 1-9. doi:10.1016/j.palaeo.2012.06.021.

Díaz-Martinéz I., Pérez-García A. 2012. Historical and comparative study of the first Spanish vertebrate paleoichnological record and bibliographic review of the Spanish Chirotheriid footprints. Ichnos 19: 141-149. doi:10.1080/10420940.2012.685565.

Elbroch M, Marks E. 2001. Bird Tracks and Sign of North America, 457. Mechanicsburg: Spackpole Books.

Fredlund MD, Wilson GW, Fredlund DG. 2002. Use of the grain-size distribution for estimation of the soil-water characteristic curve. Canadian Geotechnical Journal 39: 1103-1117.

Frey SE, Gingras MK, Dashtgard SE. 2009. Experimental studies of gas-escape and water-escape structures: Mechanisms and morphologies. Journal of Sedimentary Research 79: 808-816. doi:10.2110/jsr.2009.087.

Goethe F. 1956. Die Silbermöwe. Die Neue Brehm-Bücherei No. 182, 95. Wittenberg: Ziemsen.

Hitchcock E. 1858. Ichnology of New England: A Report on the Sandstone of the Connecticut Valley, especially its Fossil Footmarks, 220. Boston: W. White.

Hüppop O, Hüppop K. 2009. Atlas zur Vogelberingung auf Helgoland Teil 5: Ringfunde von 1909 bis 2008. Vogelwarte - Zeitschrift für Vogelkunde 47: 189-249.

Ishigaki S, Lockley MG. 2010. Didactyl, tridactyl and tetradactyl theropod trackways from the Lower Jurassic of Morocco: evidence of limping, labouring and other irregular gaits. Historical Biology 22: 100-108. doi:10.1080/08912961003789867.

Kirkham IR, Montevecchi WA, Lien OJ, Sklepkovych BO, Butler RG. 1987. Damage to Leach's Storm-Petrel feet. Ornis Scandinavica 18: 61-64. 
Knipe RJ. 1989. Deformation mechanisms - recognition from natural tectonics. Journal of Structural Geology 11: 127-146. doi:10.1016/0191-8141(89)90039-4.

Lockley MG, Hunt AP, Moratalla J, Matsukawa M. 1994. Limping Dinosaurs? Trackway evidence for abnormal gaits. Ichnos 3: 193-202. doi:10.1080/10420949409386388.

Lull RS. 1904. Fossil Footprints of the Jura-Trias of North America. Memoirs of the Boston Society of Natural History, vol. 5, 536. Boston: Boston Society of Natural History.

Marston JO, Vakarelski IU, Thoroddsen ST. 2012. Sphere impact and penetration into wet sand. Physical Review E 86: 020301-1-020301-5. doi:10.1103/PhysRevE.86.020301.

Marty D, Strasser A, Meyer CA. 2009. Formation and taphonomy of human footprints in microbial mats of present-day tidal-flat environments: Implications for the study of trace fossil footprints. Ichnos 16: 127-142. doi:10.1080/10420940802471027.

McCrea, RT, Tanke DH, Buckley LG, Lockley MG, Farlow JO, Xing L, Matthews NA, Helm CW, Pemberton SG. 2015. Vertebrate ichnopathology: Pathologies inferred from dinosaur tracks and trackways from the Mesozoic. Ichnos 22: 235-260. doi:10.1080/10420940.2015.1064408.

Moodie, R. L. 1923. Paleopathology. An Introduction to the Study of Ancient Evidences of Disease, 567. Urbana: University of Illinois Press.

Morse DH, Buchheister CW. 1977. Age and survival of breeding Leach's Storm-Petrels in Maine. Bird-Banding 48: 341-349.

Nothdurft W. 2012. Kohlmeisen Parus major mit Behinderungen durch Verletzungen ihrer Extremitäten: Fünf Fälle in einem Brutkollektiv. Ornithologische Mitteilungen 64: 267-275.

Reineck H-E, Singh IB. 1980. Depositional Sedimentary Environments, $2^{\text {nd }}$ edition. 549, Berlin, Heidelberg, New York: Springer.

Sacchi E, Cifelli R, Citton P, Nicosia U, Romano M. 2014. Dimetropus osageorum n. isp. from the Early Permian of Oklahoma (USA): A trace and its trackmaker. Ichnos 21: 175-192. doi:10.1080/10420940.2014.933070.

Seilacher A. 1953. Studien zur Palichnologie. I. Über die Methoden der Palichnologie. Neues Jahrbuch für Geologie und Paläontologie, Monatshefte 96: 421-451.

Seilacher A. 2008. Biomats, biofilms, and bioglue as preservational agents for arthropod trackways. Palaeogeography, Palaeoclimatology, Palaeoecology 270: 252-257. doi:10.1016/j.palaeo.2008.07.011.

Vauk-Hentzelt E. 1982. Mißbildungen, Verletzungen und Krankheiten auf Helgoland erlegter Silbermöwen. Niedersächsischer Jäger 15: 700-702. 